\title{
bmj.com at 20 years
}

\author{
The end of the beginning
}

\section{David Payne digital editor, Tony Delamothe deputy editor}

\author{
The BMJ, London WC1H 9JR, UK
}

When we registered the URL "bmj.com" there were fewer than 20000 websites in the world. Now there are nearly one billion. When we launched the world's first general medical website with a substantial web presence, 20 years ago this month, 40 million users could access the world wide web.[1] Now over three billion people— $40 \%$ of the world's population—can. The arrival of the web was one of the biggest things that happened in the past few decades; it was certainly the biggest thing that happened to this journal.

We embraced it so enthusiastically because it provided an almost miraculous escape from the limitations of print publication. Our frustrations included the length of time the print journal took to reach non-UK recipients and word limits that restricted how much authors could say. In those days, "interactivity" meant seeing your letter to the editor published five to six months after submission (if you were lucky). By contrast, the web allowed us to get all our content on to the desktops of a whole new international audience, from the moment of publication, and to provide an easy conduit for feedback.

Initially, we provided only a taster of the print journal's content online, but users quickly demanded the journal's full text, which we have provided since 1998. This entailed moving our web operation to HighWire Press at Stanford University, California, which was just beginning to publish online journals for academic publishers. ${ }^{2}$ In the beginning, all journal content was free. While original research articles are still free, other content from the print journal has been behind a pay wall since 2005 . We are now formally an "open access" journal, with a Creative Commons licence and publishing charges to defray the costs of keeping research articles free. ${ }^{3}$

Early on, we succumbed to the temptation of posting much more content online than in the print journal. Whereas the online journal had begun as a subset of the print journal, soon it was the other way around, and now this is even more the case. In 1999, we began publishing shortened versions of research articles in the print journal, ${ }^{4}$ which now run to a single page. ${ }^{5}$ Meanwhile, the full version is available online, along with its prepublication history (comprising original submissions, the comments of peer reviewers and the journal's editorial committee, and all related correspondence), fulfilling our long held commitment to open peer review. ${ }^{6}$ We moved to continuous online publication in 2008, severing any link between an article's publication date in print and online (and necessitating the adoption of unique article identifiers, which omit page numbers). ${ }^{7}$

\section{An act of stupendous generosity}

Part of the extra content online was made up of rapid responses submitted to previously published articles-some 100000 responses to date, all freely accessible. We've stuck to our original pledge to post all but the libellous, gratuitously rude, trivial, irrelevant, or incomprehensible or those that disclose patients' details without their consent. ${ }^{8}$ Further content came in the form of our digitised back archive-all the way back to 1840 - provided to us at no cost by the US National Library of Medicine in an act of stupendous generosity.

More recent online-only content has included blogs, videos, and podcasts, which can attract as much or more interest than traditional journal articles. ${ }^{9}$ Short, user generated video abstracts, podcast interviews with authors, and infographics tailored to the web-all shared through social media-provide alternative entry points into the journal's content.

Not just new forms of online content but platforms for accessing it have been rapidly evolving. Four years ago we launched a version of the journal for the iPad, making The BMJ the first general medical journal to appear in the iTunes store. A version for Android tablets launched this week. Access to thebmj.com was optimised for mobile phone use last year, and now combined mobile and tablet use comprises one quarter of the traffic online.

The journal's website has undergone multiple redesigns over the past 20 years, mostly to "declutter"-an omnipresent challenge in a world of proliferating content. While all content on thebmj.com is still available to all users, we have three "country windows"- for the UK, US, and India—and an international window for the rest of the world; these "surface" relevant content for the different territories. Social media is becoming increasingly important in directing readers to the journal, with Twitter and Facebook featuring among the top 10 sites referring visitors to us.

It's a far cry from 20 years ago, when we could only speculate what readers, subscribers, and advertisers wanted, and whether 
they would follow us online. Now we know: the site receives about 1.3 million user sessions a month (compared with The $B M J$ 's weekly print run of 120000 ). Currently, some $70 \%$ of the journal's subscription comes from online access only, or includes online access, and $27 \%$ of the journal's advertising revenue (excluding adverts for jobs and courses) comes from online.

If in its early years the status of the journal's website within the publishing group was akin to that of Pluto in our solar system, it now finds itself lodged firmly at the centre. In the process, it's undergone a name change-from bmj.com to thebmj.com-to match the journal's rebranding as The BMJ last year. ${ }^{10}$ Many of the changes we've made to the website over the years have been in direct response to users' questions, criticisms, and advice. We feel that we've already come a long way together, but we know that the journey has only just begun.
Competing interests: We have read and understood BMJ policy on declaration of interests and have no relevant interests to declare.

Provenance and peer review: Commissioned; not externally peer reviewed.

Delamothe T. BMJ on the internet. BMJ 1995;310:1343.

Delamothe T, Smith R. The BMJ's website scales up. BMJ 1998:316:1109.

Godlee F, Groves T. Open access publication fees at the BMJ. BMJ 2010;341:c4494. Delamothe T, Müllner M, Smith R. Pleasing both authors and readers. BMJ 1999:318:888.

Groves T, Schroter S. BMJ pico for original research in the print BMJ. BMJ 2009;339;b3168.

6 Groves T, Loder E. Prepublication histories and open peer review at The BMJ. BMJ 2014;349:g5394.

7 Godlee F, Delamothe T, Smith J. Continuous publication. BMJ 2008;336:1450. Davies S, Delamothe T. Revitalising rapid responses. BMJ 2005;330:1284.

9 Smith R. Dying of cancer is the best death, 31 Dec 2014. http://blogs.bmj.com/bmj/2014/ 12/31/richard-smith-dying-of-cancer-is-the-best-death/.

10 Payne D, Abbasi K, Godlee F, Delamothe T. The BMJ, the definite article. BMJ 2014;348:g4168.

Cite this as: BMJ 2015;350:h2821

(๑) BMJ Publishing Group Ltd 2015 